\title{
ROLE OF ICT AS A CONTINGENCY FACTOR IN FINANCIAL SECTOR DEVELOPMENT, REMITTANCES, AND ECONOMIC GROWTH NEXUS: AN EMPIRICAL STUDY OF INDONESIA
}

\author{
Keshmeer Kanewar Makun* and T.K. Jayaraman** \\ * School of Economics, University of the South Pacific, Suva, Fiji. Email: keshmeer.e.makun@usp.ac.fj \\ ** Department of Economics, International Research Collaborative Program, University of Tunku Abdul \\ Rahman, Malaysia. Email: tkjayaraman@yahoo.com
}

\begin{abstract}
This study examines the role of ICT as a factor in Indonesia's financial sector development, remittances, and economic growth nexus using annual data from 19842017. We use the bounds testing procedure based on the Autoregressive Distributed Lag framework and the neoclassical growth model. The findings of the study reveal that ICT has indeed emerged as a significant factor in the remittance-growth nexus by playing a complementary role in financial sector development. The policy implication is that ICT needs to be supported at all levels and the financial inclusion process should be carried forward as it has all the potential to speed up economic growth and development.
\end{abstract}

Keywords: ICT; Remittances; Financial Sector Development; Economic Growth.

JEL Classifications: E44; F24; O16; O33.

Article history:

Received : October 17, 2019

Revised : : December 18, 2019

Accepted : July 09, 2020

Available online : September 09, 2020

https://doi.org/10.21098/bemp.v23i3.1180 


\section{INTRODUCTION}

Annual Flows of Remittances ${ }^{1}$ (REM) to Low- and Middle-Income Countries (LMICs) in recent years have emerged to be not only more reliable but also have become larger than the traditional capital transfers, which include Official Development Assistance (ODA), popularly known as foreign aid, besides Foreign Direct Investment (FDI). The World Bank's annual publication, Migration and Development Brief (World Bank, 2018) reports that global REM flows in 2018 reached a new high at $\$ 528$ billion.

Indonesia with per capita Gross National Income (GNI) at US\$ 3,540 in 2017 prices, belonging to the group of LMICs, is no exception. It has been experiencing a rising trend in REM inflows during the last few years. It was among the world's top ten REM remittance recipient countries until 2017. Although dislodged to a rank below ten in 2018, Indonesia continues to be among the top ten remittances recipient countries in East Asia and the Pacific region. Being in foreign currencies, annual REM inflows from Indonesians working overseas estimated at 4.2 million in 2017 (United Nations, 2017) are additions to the country's real resources, which would have to be earned under normal circumstances through exports of goods and services including tourism. Most importantly, as they happen to supplement the income of families left behind in the rural and remote parts of the country, their biggest contribution lies in the area of alleviation of poverty.

A growing literature on the relationship between remittances and economic growth in developing countries since the beginning of the New Millennium (Chami et al., 2008; Amuedo-Dorantes and Pozo, 2010; Mongardini and Rayner, 2009; Adams and Page, 2005) have also been stressing the need for mobilizing the resources from the steady annual inflows of REM. This is because savings out of REM in the absence of opportunities to access to banking services in rural areas and remote islands are observed to be spent on wasteful consumption.

On the other hand, the emergence of Information and Communication Technology (ICT) since the mid-1990s, as a factor towards boosting output and labor productivity, has attracted wide attention. The rapid spread of ICT with mobile voice and data networks has resulted in improving access to financial services, which has promoted banking habits including depositing and savings out of regular remittance inflows to rural families (Mohan and Ray, 2017). There is a significant increase in account holders with banks, mobile money accounts as well as digital payments in recent years. Indonesia is the fourth most populous country and poses a fast-evolving market for ICT development.

To the best of our knowledge, the available empirical studies on Indonesia's remittances and growth ${ }^{2}$ have not specifically examined the roles of ICT and financial markets in REM and economic growth nexus. This is essential as mobilization of savings by banks and other financial sector institutions, also

\footnotetext{
1 The World Bank (2019) defines the term remittances as the sum of personal transfers and compensation of employees. Personal transfers include all current transfers in cash or in kind between resident and nonresident individuals, independent of the source of income of the sender. Compensation of employees refers to the income of border, seasonal, and other short-term workers who are employed in an economy.

2 These include Hartarto and Azizurrohman (2018), Bachtiar (2011), Parinduri and Thangavelu (2011), Adams Jr and Alfredo Cuecuecha (2010).
} 
referred to as financialization of savings adds to reserves in banks thereby enabling them to step up greater lending to a large number of aspiring entrepreneurs in their small enterprises in non-banked areas. Credit growth is a logical consequence of financial deepening and Financial Sector Development (FSD), one of the indicators along with rising deposits (Aggarwal et al., 2011). More importantly, the quality and quantum of credit flow to the hitherto bypassed sections of the community would also make the difference (Ebeke et al., 2014).

The only recent econometric study available on growth and REM relationship in Indonesia is by Nahar et al. (2018). By using the OLS method the study shows that REM and foreign aid have a positive effect on GDP while trade openness has a negative effect. The shortcoming of this study is that it does not appropriately conduct the stationary test of the variables and cointegration relationship among the variables. Like many other trended series, variables in the model could have unit root and are expected to be cointegrated in the long run. However, the presence of unit root is likely to produce a spurious result (Granger and Newbold, 1986). The other limitation of this study is that it attempted to study economic growth without the fundamental variables of capital stock and labor. Bosworth and Collins (2003) distinguished between the two fundamental variables in any growth equation and other potential determinants of growth. Rao and Rao (2005) argue that the fundamental variables should be retained in any subsequent regressions to analyze the significance of other potential determinants, which are called shift variables. Cointegrating equations or any effort to run growth regressions without capital stock and labor variables are therefore suspect, as they suffer from bias arising from errors of omission as well as misspecification (Rao and Rao, 2009).

The present paper is, therefore, motivated by these developments and particularly the desire to bestow attention on the rapid rise of ICT and further promotion of financial inclusion, thereby deepening the financial sector for remittances inflow and consequently enhancing economic growth. Indonesia is the top ten remittance recipient in East Asia and the Pacific region. Despite a stable rise in economic growth and financial inclusion efforts in recent years, Indonesia stills lag in financial sector development and ICT relative to neighboring Asian economies like Singapore and Malaysia. Thus, understanding the role played by ICT and FSD in the remittances-growth nexus is important. Our approach to the econometric analysis of the impact of remittances, FSD, and ICT spread on economic growth is different from the above-mentioned studies. We use timeseries techniques of the Autoregressive Distributed Lag (ARDL) model. Designed by Pesaran et al. (2001), the Bounds test within the ARDL framework has been widely employed in recent years to investigate long-run relation amongst time series factors. However, there is no precedent of examining ICT, FSD, remittances, and growth nexus using this approach. Further, this approach is more robust and performs well with small sample observations (Ishida, 2015).

Our analysis offers the following insights. There exist a long-run cointegration relationship between REM, FSD, ICT, and economic growth. Remittances, along with financial development and ICT exert a positive impact on real GDP per capita. The interaction term of FSD and ICT is positive, indicating that they are complementary to Indonesia's long-run economic growth. The findings further show that apart from REM inflow, capital stock enhances economic growth in 
Indonesia which is consistent with previous literature. To check for robustness, we introduce structural breakpoints based on Narayan and Popp (2010) and control variables in the remittances-growth model. We find a positive effect of ICT, FSD, and remittances, which is consistent with our earlier findings. The results further show that both human capital and trade openness enhance long-run economic growth in Indonesia.

The balance of the paper is organized as follows. The next section provides a brief literature review of theoretical and empirical studies on REM, financial sector development, ICT, and economic growth nexus. Section III discusses trends in remittances, FSD and ICT spread in Indonesia. Section IV outlines theoretical framework and methodology. Section $\mathrm{V}$ provides data and the results while the final Section VI provides conclusion.

\section{BRIEF REVIEW OF LITERATURE}

A. REM and Economic Growth

There is a large volume of literature, theoretical and empirical, concerning REM and economic growth nexus since the beginning of the New Millennium. Benefits derived by LMICS from inflows of REM, which are summarized from various studies (Leon-Ledesma and Piracha, 2001; Edwards and Ureta, 2003; Page and Adams, 2003; Hildebrandt and McKenzie, 2005; Yang, 2008; and Giuliano and Ruiz-Arranz, 2009) include the following: (i) regular REM inflows to LMICs promote the wellbeing of the families left behind by migrants; (ii) assist the beneficiaries in upgrading their dwellings; (iii) improve their farming and other earning activities; (iii) help households to pay children's education fees and bear the costs of the aged dependents' medical care. Further, REM inflows add to the beneficiary nation's foreign reserves, raising their creditworthiness in the eyes of international financing agencies, thereby enabling them to borrow to funding growth-enhancing investments.

On the other hand, there are studies (Ratha and Mohapatra, 2007; Jayaraman et al, 2016; Bachtiar, 2011) drawing attention to the negative effects of rising REM as well. They include (i) brain drain; (ii) use of remittances for imports for luxury goods and resultant widening of trade deficits; and (iii) rise in domestic price level due to higher consumption of non-tradable goods and services, resulting in the appreciation of real exchange rate and adversely affecting the competitiveness of exports, known as 'Dutch disease'. There are, however, remedial measures, which include investment in the utilization of increased foreign reserves in funding infrastructure projects including water supply and power generation, which bring down the domestic price level relative to the foreign price level (Jayaraman et al., 2016).

Studies concerning Indonesia have given various insights on the impact of remittances on household consumption and investment, gender dimension, human capital development, and poverty reduction. The notable ones include Adams and Cuecuecha (2013), Bachitiar (2011), Rahman (2010), Parinduri and Thangavelu (2011), Nahar and Arshad (2017), and Nahar et al (2018). In regards to household consumption, Indonesians receiving remittance spent more on food than what they would have spent without remittance (Adams and Cuecuecha, 
2010). Bachitar (2011) observed that as recipients of remittances were generally poorer households, they were less likely to spend their remittances on investment goods. Further, even though women migrants earned less than men migrants, they turned out to be better savers and remitted a larger share of their earnings than men (Rahman, 2010). On the impact of remittances on human capital, Parinduri and Thangavelu (2011) observed a large part of remittances was spent on school fees and education-related expenses. Nahar and Arshad (2017) show that although remittances had a negative association with poverty at the household level, its contribution to poverty alleviation in Indonesia was small.

\section{B. FSD, REM, and Economic Growth}

The developmental effect of REM can be enhanced when savings from remittances are mobilized in financial markets by recycling them as credit (Jayaraman et al., 2018). In the absence of financial markets including banking services in the rural areas, a major proportion of REM recipients are not able to put their savings in financial institutions as deposits. About $80 \%$ of micro and small businesses in LMICs who do not have access to bank credit are compelled to look for funds at much higher rates of interest outside the formal financial sector (Mashayekhi, 2014). In such cases, where the debtors have no guarantee to offer, they put their future REM receipts as securities (Paulson and Townsend, 2000). To improve access to urban-based banks, which are reluctant to open their branches in rural and inaccessible regions on cost considerations, the United Nations included financial inclusion as a major goal in its post-2015 Development Framework. Financial inclusion is defined as "successful access to reasonable and sustainable financial services from formal suppliers" (United Nations, 2015). These initiatives have given a big boost to the poverty alleviation efforts since 2001 (African Union, 2009).

Studies incorporating FSD in remittances and growth nexus (Calderon et al. 2008; Ramirez and Sharma, 2008; Giuliano and Ruiz-Arranz, 2009; Nyamongo et al., 2012; Bettin and Zazzaro, 2009) came to a general conclusion that REM served as an alternate source of funding for micro and mini enterprises to bank loans. Giuliano and Ruiz-Arranz (2009) observe that in countries where financial sectors are weak, remittances become a substitute for bank finance. On the other hand, where financial sectors are strong and where liquidity limitations do not represent an issue, remittances may be utilized for consumption spending. However, Zouheir and Sghaier (2014) show contrasting evidence concerning FSD, remittances, and growth. In African countries, where financial markets are less developed, the two variables act as complements, reinforcing each other, and enhance the positive effect of remittances on growth. As the financial sector brings a larger share of the population in contact with banks, remittances passing through formal channels expand the availability of credit (Aggarwal et al., 2011). Further, in a panel study, Chowdhury (2016) suggests that while remittances alone were found to be active in stimulating growth, the impact of financial markets on growth was insignificant and that financial sector development neither a substitute nor a complement in the remittance-growth nexus. 


\section{ICT and Economic Growth}

Studies on ICT and economic growth nexus began in the early 1990s. For instance, Cronin et al, (1991) examined the causal long-run relation between ICT development and economic growth in the US and show evidence of a bidirectional relationship. Following this, there have been several other studies mostly in developed countries. While the majority of these studies confirmed the presence of a positive relationship from ICT to economic growth (Ahmad and Ridzuan, 2013; Kumar et al. (2015); Chakraborty and Nandi, 2003; Chu et al., 2005; Dutta, 2001; Aghaei and Rezagholizadeh, 2017; Niebel, 2018; Ayub, 2018), there are some instances of no evidence of a causal relationship between ICT and economic growth (Shiu and Lam, 2008).

Noting ICT's contribution to economic progress in the advanced countries, LMICs being latecomers are now speeding up the development of the ICT sector as a major focus of general economic reforms (Rath, 2016, Rath and Hermawan, 2019). They are getting rid of government monopolies and by encouraging competition and assisting investors in the ICT sector with joint ventures with the private sector. The ICT is now perceived as a contributor to savings in operating costs of banks which were a major reason for the hesitancy of the urban-based banks to get out of the comfort zone offered by the availability of roads and electricity and office space of brick and mortar buildings and other facilities in cities and town to spread their operations to rural and low-income regions.

Mohan and Ray (2017) point out substantial savings involved in keeping records as a single most significant advantage of ICT, which contributed to a reduction in the costs of servicing a large number of small loans to poor families. With the availability of new technology and a fall in the price of smartphones, which are used for mobile banking services in rural areas, many of the past hurdles to FSD have now faded. Empirical studies on the impact of ICT on FSD (Wilson, 1993; Radeck et al., 1997; Freund et al., 1997; Jordan and Katz, 1999) confirm a positive correlation between ICT investment and bank efficiency. More recently, Pradhan et al (2017) found that there is a long-run relationship between ICT penetration, FSD, and economic growth. The panel study shows that causality linkages ran from ICT penetration and FSD to economic growth.

While there is considerable literature on FSD, remittances, and growth independently, not much has been done to understand the link between these variables together in developing countries with exclusive consideration to single country analysis. We examine the role of ICT and FSD in remittances-growth nexus. The extant literature did not take into consideration the role of ICT in the remittances-growth nexus. In recent times ICT has become an important conduit for capital transfers including remittances and accessing financial markets products. Hence, the present study adds to the extant literature by addressing these important issues in understanding the remittances-growth nexus in Indonesia. Analysis of a single country provides a deeper understanding of how remittances impact growth with the presence of ICT and FSD (Rath and Hermawan, 2019). To the best of our knowledge, this paper is the first to analyze the role of ICT in financial sector development, remittances, and growth nexus. 


\section{TRENDS IN REMITTANCES, FSD, AND ICT IN INDONESIA}

\section{A. Remittances}

Indonesia with a population of around 264 million and a GDP of $\$ 1,015$ billion and per capita GDP of US\$3,846,(both in current prices of 2017) is one of the world's large REM recipient countries in terms of US dollars. Table 1 presents the worldwide flows of capital transfers to LMICs and Indonesia both in terms of dollars in current prices and in terms of percentages of GDP. They show REM flows have exceeded the traditional flows of ODA and FDI. Although in terms of percentage of GDP remittances are a small proportion, Indonesia has been among the world's top ten recipients in 2016 and 2017. It has also been among the top REM recipient countries in East Asia and the Pacific region (excluding highincome countries) for the last three years (2016 to 2018).

Table 1.

\section{Capital Transfers (US\$ billion): World, LMICs and Indonesia 2005-2017}

This table provides data on foreign aid, FDI, and remittances inflow for World, LMICs, and Indonesia from World Bank (2019). Figures in parentheses are in percentages of GDP.

\begin{tabular}{lccccccccc}
\hline & $\mathbf{2 0 0 5}-\mathbf{0 9}$ & $\mathbf{2 0 1 0}$ & $\mathbf{2 0 1 1}$ & $\mathbf{2 0 1 2}$ & $\mathbf{2 0 1 3}$ & $\mathbf{2 0 1 4}$ & $\mathbf{2 0 1 5}$ & $\mathbf{2 0 1 6}$ & $\mathbf{2 0 1 7}$ \\
\hline World & & & & & & & & & \\
\hline Foreign Aid & 115.29 & 130.94 & 141.90 & 133.77 & 151.14 & 161.52 & 153.21 & 158.22 & 159.22 \\
& $(0.21)$ & $(0.20)$ & $(0.19)$ & $(0.18)$ & $(0.20)$ & $(0.20)$ & $(0.20)$ & $(0.21)$ & $(0.20)$ \\
FDI & 2130.19 & 1863.65 & 2290.27 & 2118.66 & 2136.90 & 1860.63 & 2411.36 & 2458.33 & 2459.33 \\
& $(3.74)$ & $(2.74)$ & $(3.03)$ & $(2.72)$ & $(2.57)$ & $(2.28)$ & $(3.15)$ & $(3.16)$ & $(2.35)$ \\
Remittances & 338.81 & 418.67 & 470.27 & 495.47 & 525.18 & 559.36 & 564.51 & 549.69 & 550.69 \\
& $(0.61)$ & $(0.65)$ & $(0.65)$ & $(0.67)$ & $(0.69)$ & $(0.72)$ & $(0.77)$ & $(0.74)$ & $(0.73)$ \\
\hline LMICs & & & & & & & & & \\
\hline Foreign Aid & 115.04 & 130.27 & 141.31 & 133.28 & 150.87 & 161.50 & 153.12 & 157.97 & 158.97 \\
& $(0.87)$ & $(0.65)$ & $(0.60)$ & $(0.53)$ & $(0.57)$ & $(0.58)$ & $(0.58)$ & $(0.60)$ & $(0.56)$ \\
FDI & 453.33 & 610.86 & 722.04 & 651.60 & 737.57 & 664.89 & 628.55 & 560.04 & 561.04 \\
& $(3.30)$ & $(3.03)$ & $(3.05)$ & $(2.57)$ & $(2.74)$ & $(2.38)$ & $(2.41)$ & $(2.14)$ & $(1.88)$ \\
Remittances & 234.96 & 301.54 & 339.90 & 366.91 & 387.48 & 416.50 & 431.32 & 415.75 & 416.75 \\
& $(1.74)$ & $(0.65)$ & $(0.60)$ & $(0.53)$ & $(0.57)$ & $(0.58)$ & $(0.58)$ & $(0.60)$ & $(0.56)$ \\
\hline Indonesia & & & & & & & & & \\
\hline Foreign Aid & 1.39 & 1.39 & 0.40 & 0.07 & 0.07 & -0.38 & -0.03 & -0.11 & 0.89 \\
& $(0.39)$ & $(0.19)$ & $(0.05)$ & $(0.01)$ & $(0.01)$ & $(-0.04)$ & $(0.00)$ & $(-0.01)$ & $(0.02)$ \\
FDI & 6.87 & 15.29 & 20.56 & 21.20 & 23.28 & 25.12 & 19.78 & 4.54 & 5.54 \\
& $(1.72)$ & $(2.03)$ & $(2.30)$ & $(2.31)$ & $(2.55)$ & $(2.82)$ & $(2.30)$ & $(0.49)$ & $(2.11)$ \\
Remittances & 6.18 & 6.92 & 6.92 & 7.21 & 7.61 & 8.55 & 9.66 & 8.91 & 9.91 \\
& $(1.50)$ & $(0.92)$ & $(0.78)$ & $(0.79)$ & $(0.83)$ & $(0.96)$ & $(1.12)$ & $(0.96)$ & $(0.89)$ \\
\hline \multirow{2}{*}{ Fin } & & & & & & & & &
\end{tabular}


The trend is clear. While the Indonesian migrants residing and working outside the country have risen from 2.34 million in 2005 to an estimated 9 million in 2017, REM inflows have also risen from US\$ 6.18 billion in 2005 to US\$ 9.91 billion in 2017. As recorded by World Bank (2018), REM flows to LMICs are now more than three times the size of foreign aid. They are also significantly larger than FDI. In the case of Indonesia, foreign aid has declined from US\$ 1.39 billion in 2005 to US\$ 0.89billion in 2017 and FDI decreased from the highest at US\$ 25.12 billion in 2014 to 5.54 billion in 2017.

According to the World Bank's Migration and Development Brief 30, 2018, the growth rate in REM to the East Asia Pacific region in 2017 was 5.5\%. The World Bank forecasts are that REM is expected to grow in 2018 by $6.6 \%, 4.2 \%$, and $4.7 \%$ in 2019 and 2020 respectively. There is optimism that with new Japanese legislation coming into effect from April 2019, allowing inflows of two types of foreign workers: (i) low-skilled foreign workers who would reside in Japan for up to five years and work in 14 specific sectors, including farming, construction, hospitality, and shipbuilding sectors, without family members and (ii) foreign workers with a higher level of skills who would be allowed to bring their family members and could be allowed to live in Japan indefinitely. Further, Malaysia is reported to shift at least some of the responsibility for the recruitment of foreign workers by private agencies to the Ministry of Human Resources. It is also reported to be considering the revision of its levy system on local employers hiring foreign workers to a model closer to Singapore's multi-tier levy, which is more liberal (World Bank, 2018).

\section{B. Financial Sector and ICT}

Indonesia's financial sector is relatively small with assets around 75\% of GDP, compared to other Association of Southeast Asian Nations (ASEAN) countries. Further, the banking sector dominates with $80 \%$. More than $40 \%$ of 118 commercial banks are in the public sector, another $40 \%$ being in the private sector and the remaining being owned by foreign interests. Five top banks own nearly $47 \%$ of the total assets of the financial sector. As the corporate bond market has not developed, bonds are sovereign and in local currency and further, they are mostly held by banks. The asset size of Non-Bank Financial Institutions (NBFIs) is relatively small compared to those of commercial banks and nearly $87 \%$ of them are held by insurance companies and pension funds. The remaining NBFI assets are held by financing companies, which include multi-finance, venture capital, and infrastructure financing companies, pawnshops, and export-import bank.

The high cost of intermediation is a reflection of low bank penetration and its inability to mobilize savings from rural areas and remote islands (Aziz, 2018). Sources of funds are predominantly short-term (more than 90\% having onemonth maturity) and about half of them are current and savings accounts (Aziz, 2018). The serious challenge to the financialization of savings is posed by hurdles of poor communication between the islands. Commercial banks are reluctant to open and operate branches in remote islands away from the comfort zones of uninterrupted supply of electricity and other facilities. The financial exclusion of a large proportion of the population was a reality. Aziz (2018) observes that just around more than one-third of Indonesia's population (15 years and older) has 
a financial institution account. Among the poorest $40 \%$ of the population, only $22 \%$ have a bank account. A jointly sponsored study by World Bank and IMF on financial sector assessment study noted that Indonesia with its large population and relatively low access rate, the unbanked population is the third-largest in the world (World Bank 2017b). It is reported among the 58 million small and medium businesses in Indonesia, only 12\% have access to credit because of the deficiency of credit history, statements, or collateral, although contributions from these small and medium businesses account for around $60 \%$ of Indonesia's GDP.

A World Bank (2010) sponsored survey on household access to financial services in Indonesia revealed only $49 \%$ of the population had access to the formal banking sector and when combined with NBFIs, 52\% of the population had access to financial products offered by the formal sector. Accordingly, more than 110 million had no access to formal sector financial institutions. Further, it is revealed by the survey that only $31 \%$ of the population had recourse to the informal sector. The remaining $17 \%$ or 40 million people have been excluded financially. Aside from a lack of collateral and other difficulties, the single most important reason is the absence of a bank account, which is due to the lack of a job or income. With the regular and steady receipt of remittances from overseas, more families can open a savings account in the bank.

With the advent of the ICT revolution since the beginning of the New Millennium, the government formally launched the National Financial Inclusion Strategy $\left(\mathrm{SNKI}^{3}\right)$ in 2016. The SNKI's goal is to make $75 \%$ of adults to have a bank account in the next four years (World Bank, 2017b) through the issue of new electronic money primarily through the spread of mobile phone ownership. The World Bank study (2017b) signals out promoting Digital Financial Services $(\mathrm{DFS})^{4}$ as the key component of SNKI. With a flourishing financial technology (Fin-Tech) sector comprising more than 100 companies operating in Indonesia has revolutionized the provision of financial services and products. The central bank has categorized the Fin-Tech firms as follows: (i) payment, clearing, and settlement; (ii) raising deposits and lending services; (iii) market provisioning; and (iv) risk management. The World Bank study shows $42 \%$ of Fin-Tech firms are in payment services and around $32 \%$ in person to person lending in the country. The e-money issuers (banks and nonbanks) as well as other banks providing basic saving accounts and other financial services are expanding service delivery outreach. Agents are now available in all provinces, covering almost $99 \%$ of the districts, and enabling opening registered e-money and providing access to cashin, cash-out, bill payments, and transfer services through registered e-money. The government agencies began to use e-money for paying salaries and other cash payments such as subsidies through "Combo Card" (Basic Saving Account and registered e-money in one card), which was hitherto done only by state-owned banks.

Until the mid-2000s, nearly $99 \%$ of transactions were in cash. With the popularity of e-money and other innovative payment steps, notable progress

\footnotetext{
SNKI stands for Strategi Nasional Keuangan Inklusif (National Financial Inclusion Strategy).

4 The term digital financial services (DFS) is used by Indonesia's central bank to refer to as tailored financial services and products delivered through channels other than traditional bank branches.
} 
towards less and less cash society has been made. As of December 31, 2016, there were around 17.4 million credit cards issued in Indonesia. The use of a credit card is a preferred payment, since the customers do not have to keep cash, nor they have to rush to the bank or look for an Automatic Teller Machine (ATM). Further, a credit card also serves record-keeping with regular transaction statements for expenses and spending tracking.

Table 2 presents financial inclusion indicators, tracing the steady progress recorded by Indonesia. As regards to accounts with banks and other financial institutions as well as mobile money accounts, Indonesia lags behind LMICs and East Asia and Pacific region. However, regarding digital payments, Indonesia is ahead of LMICs. But, its progress is far behind other countries in the EAP region.

Table 2.

Financial Inclusion Indicators: World, LMICs, East Asia Pacific (EAP), and Indonesia

This table provides financial inclusion indicators as well as ICT related activities in Indonesia's financial sector development. The statistics are obtained from the World Bank (2018).

\begin{tabular}{|c|c|c|c|c|c|}
\hline & & World & LMIC & EAP & Indonesia \\
\hline Population Age + 15 & & $5.5 \mathrm{~B}$ & $4.5 \mathrm{~B}$ & $1.6 \mathrm{~B}$ & $188.9 \mathrm{M}$ \\
\hline GNI ( per capita) US\$ & & 10,308 & 4,441 & 6,667 & 3,400 \\
\hline \multicolumn{6}{|l|}{ Account with Banks ( $\%$, Age +15$)$} \\
\hline All adults & 2017 & 68.50 & 57.80 & 70.60 & 48.90 \\
\hline & 2014 & 62.00 & 41.90 & 69.10 & 36.10 \\
\hline & 2011 & 50.60 & 28.90 & 55.10 & 19.60 \\
\hline \multicolumn{6}{|l|}{ Financial Institutions Account } \\
\hline \multicolumn{6}{|l|}{ All adults $(\%$, Age +15$)$} \\
\hline & 2017 & 67.10 & 56.10 & 70.30 & 48.40 \\
\hline & 2014 & 61.20 & 40.60 & 68.90 & 35.90 \\
\hline & 2011 & 50.60 & 28.90 & 55.10 & 19.60 \\
\hline \multicolumn{6}{|l|}{ Mobile Money Account } \\
\hline \multicolumn{6}{|l|}{ All adults $(\%$, Age +15$)$} \\
\hline & 2017 & 4.40 & 5.30 & 1.30 & 3.10 \\
\hline & 2014 & 2.10 & 3.20 & 0.40 & 0.40 \\
\hline \multicolumn{6}{|l|}{ Account by Individual Characteristics } \\
\hline & 2017 & & & & \\
\hline Women & & 64.80 & 53.00 & 67.90 & 51.40 \\
\hline Adults belonging to poorest $40 \%$ & & 60.50 & 50.70 & 59.30 & 36.60 \\
\hline Adults in labour force & & 58.30 & 50.80 & 59.80 & 42.10 \\
\hline Adults in rural area & & 66.00 & 57.60 & 68.80 & 47.00 \\
\hline \multicolumn{6}{|l|}{ Digital payments in the past year } \\
\hline \multicolumn{6}{|l|}{$(\%$, age +15} \\
\hline \multicolumn{6}{|l|}{ Made or received payments } \\
\hline & 2016 & 52.30 & 29.20 & 58.00 & 34.60 \\
\hline & 2013 & 41.50 & 19.70 & 39.00 & 22.40 \\
\hline
\end{tabular}


Table 2.

Financial Inclusion Indicators: World, LMICs, East Asia Pacific (EAP), and Indonesia (Continued)

\begin{tabular}{|c|c|c|c|c|}
\hline & World & LMIC & EAP & Indonesia \\
\hline \multicolumn{5}{|l|}{ All below in 2016} \\
\hline Used an account to pay utility bills & 22.30 & 7.50 & 28.80 & 12.00 \\
\hline Used an account to receive private-sector wages & 15.90 & 5.50 & 15.90 & 5.90 \\
\hline Used an account to receive govt payments & 16.30 & 8.30 & 12.20 & 8.90 \\
\hline Used internet to pay bills or buy online & 29.00 & 6.80 & 38.60 & 11.30 \\
\hline Used mobile phone or internet to access an account & 24.90 & 8.30 & 31.00 & 7.70 \\
\hline Used debit or credit card to make a purchase & 32.60 & 6.80 & 33.10 & 12.30 \\
\hline \multicolumn{5}{|l|}{ Savings in past year $(\%$, age +15$)$} \\
\hline 2016 & 26.70 & 15.90 & 30.60 & 21.50 \\
\hline 2014 & 27.30 & 14.40 & 36.70 & 26.60 \\
\hline \multicolumn{5}{|l|}{ Credit in the past year } \\
\hline \multicolumn{5}{|l|}{ Borrowed from financial Instn/used credit card } \\
\hline 2016 & 22.50 & 9.80 & 21.50 & 18.40 \\
\hline 2014 & 22.30 & 10.00 & 19.50 & 13.70 \\
\hline
\end{tabular}

\section{FRAMEWORK AND METHODOLOGY}

\section{A. Framework}

We use the neoclassical Cobb-Douglas function to examine the effects of potential determinants as shift variables on output per capita as derived by Solow (1956) and following Rao (2010). The technological factor in Solow (1956), known as Solow residual, is an important parameter in this model. The long-run growth rate is explained by the rate of growth of technical progress (total factor productivity), which is exogenously determined. Hence, it is plausible to extend and capture the growth effects of other variables such as remittances and ICT.

Hence, following the Solow framework, the output per capita is expressed as:

$$
y_{t}=A_{t} k_{t}^{\alpha}, \quad 0<\alpha<1
$$

Where:

$y_{t}=$ output per capita.

$A_{t}=$ stock of technology also known as total factor productivity.

$k_{t}=$ stock of capital.

$\alpha=$ share of capital.

The model takes that the evolution of technology is given by:

$$
A_{t}=A_{o} e^{g t}
$$

Here, $A_{0}$ is the initial stock of technical expertise and $g$ represents the technology growth over time trend $t$. The effect of REM on $A_{t}$ (total factor productivity) is realized when the right-hand side variables come into the functional form as shift variables. Besides REM, we also introduce additional control variables such 
as financial development and ICT, and their interaction term. We choose broad money as a percent of GDP as the most representative one for FSD, since the credit data series are not complete. Regarding ICT, we choose mobile phone ownership as the proxy for ICT.

Hence, it is plausible to take that:

$$
A_{t}=f\left(R E M_{t}, B M_{t}, M O B_{t}, B M_{t}^{*} M O B_{t}\right)
$$

Where:

REM = remittances percent of GDP

$B M=$ Broad Money as a percent of GDP

$M O B=$ mobile subscription per 100 inhabitants, representing ICT.

$B M^{*} M O B=$ interaction term for FSD and ICT.

Therefore, the Cobb-Douglas function is further modified as:

$$
y_{t}=\left(A_{o} e^{g t} R E M_{t}^{\beta_{1}}, B M_{t}^{\beta_{2}}, M O B_{t}^{\beta_{3}}, B M_{t}^{*} M O B_{t}^{\beta_{4}}\right) k_{t}^{\alpha_{1}}
$$

For estimation, the above model is transformed into logs and rearranged as:

$$
\ln y_{t}=\alpha_{0}+\alpha_{1} l k_{t}+\beta_{1} l R E M_{t}+\beta_{2} l B M_{t}+\beta_{3} M O B_{t}+\beta_{4} l B M_{t} * M O B_{t}+\varepsilon_{t}
$$

We test the following hypothesis. The explanatory variable of capital per capita stock $(l k)$, remittances (lREM), FSD indicator (lBM) and ICT indicator (lMOB) are directly associated with output per capita hence, we expect these variable to be positive. For the interaction term of $B M_{t}^{*} M O B_{t}$ there is no prior conclusion. If the interaction term is estimated to be positive and significant, it would mean that the combined growth effects of interaction term are enhanced in a deeper financial system with FSD and ICT displaying a complementary relationship. However, if the interaction variable has a negative coefficient and is also significant, ICT and FSD are substitutes, whereas if the interaction variable has a negative sign and is found to be insignificant, the two variables are independent of each other.

\section{B. Methodology}

We employ the ARDL bounds testing approach (Pesaran et al., 2001) to examining the existence of cointegration between remittances, FSD, ICT, and economic growth. There are several benefits to the ARDL model. It is considered to be appropriate for a small number of observations. It enables the researcher to obtain consistent long-run and short-run estimates without losing any information. The ARDL procedure addresses endogeneity concerns among the variables (Pesaran et al., 2001). Further, in the ARDL procedure, it may not be necessary to check for unit root as it is acceptable to examine cointegration regardless of integration order. However, to ensure the robustness of the results, we applied two widely used unit root tests: Augmented Dickey-Fuller (ADF) and Phillip-Perron (PP). 
But these tests do not consider structural breaks in data. To address this, we use Narayan and Popp (2010) to capture structural breaks.

After addressing the unit root, we proceed to examine the long-run relationship between remittances, ICT, FSD, and economic growth. We derive the long run unrestricted error correction regression equation for ARDL bounds test from equation (5) as follows:

$$
\begin{aligned}
& \Delta l y_{t}=\alpha_{1}+\alpha_{2} l y_{t-1}+\alpha_{3} l k_{t-1}+\alpha_{4} l R E M_{t-1}+\alpha_{5} l B M_{t-1}+\alpha_{6} l M O B_{t-1}+\alpha_{7} l B M * M O B_{t-1}+\sum_{i=1}^{n} \beta_{1} \Delta l y_{t-i} \\
& +\sum_{i=0}^{n} \beta_{2} \Delta l k_{t-i}+\sum_{i=0}^{n} \beta_{3} \Delta l R E M_{t-i}+\sum_{i=0}^{n} \beta_{4} \Delta l B M_{t-i}+\sum_{i=0}^{n} \beta_{5} \Delta l M O B_{t-i} \sum_{i=0}^{n} \beta_{6} \Delta l B M * M O B_{t-i}+\varepsilon_{t}
\end{aligned}
$$

In equation (6), delta $(\Delta)$ is the difference operator of the corresponding series. The bounds testing is conducted as follows: First, equation (6) is run using the ordinary least square method, and secondly, the confirmation of equilibrium cointegration is traced out by putting restrictions on the coefficients of level lagged variables. The testing is done by using the F-test statistics design by Pesaran et al. (2001). The null hypothesis is that there is no cointegration (H0: $\alpha_{1}=\alpha_{2}=\alpha_{3}=\alpha_{4}=\alpha_{5}=\alpha_{6}=\alpha_{7}=0$ ) and the alternative hypothesis is that there is a cointegration (HA: $\alpha_{1} \neq \alpha_{2} \neq \alpha_{3} \neq \alpha_{4} \neq \alpha_{5} \neq \alpha_{6} \neq \alpha_{7} \neq 0$ ). When the F-statistic is higher than the critical value, then the null hypothesis is rejected in favor of the alternative hypothesis. ${ }^{5}$

Next, the error correction model is used to confirm the long-run cointegration relationship. The ECM is specified as shown in equation (7).

$$
\begin{aligned}
& \Delta l y_{t}=\alpha_{1}+\sum_{i=1}^{n} \beta_{1} \Delta l y_{t-1}+\sum_{i=1}^{n} \beta_{2} \Delta l k_{t-1}+\sum_{i=1}^{n} \beta_{3} \Delta l R E M_{t-1}+\sum_{i=1}^{n} \beta_{4} \Delta l B M_{t-1}+\sum_{i=0}^{n} \beta_{5} \Delta l M O B_{t-i} \\
& +\sum_{i=0}^{n} \beta_{6} \Delta l B M * M O B_{t-i}+\lambda_{1} E C M_{t-1}+\varepsilon_{t}
\end{aligned}
$$

The adjustment parameter $\left(\lambda_{1}\right)$ is expected to be negative and statistically significant.

\section{DATA AND RESULTS}

A. Data

The analysis covers 34 years (1984-2017), based on the availability of data. The dependent variable is real GDP per capita (in 2010 prices), represented by $y$. REM and $B M$ are in percent of GDP. The explanatory variable of ICT is represented by mobile subscriptions per 100 inhabitants $(M O B)$. The interaction term, $B M^{*} M O B$ is the product of each of the two variables. The data series for real GDP, REM, $B M$, and $M O B$ are obtained from World Development Indicators (WDI). The data

5 If the computed $F$-stats are less than the critical value, then the null hypothesis cannot be rejected. When the computed F-stats are in the middle of the critical valuess, then the result is not conclusive. 
series of capital stock (in constant 2011 prices) is obtained from Pen World Table. We compute capital per capita stock by taking the ratio of capital stock to the labor force which is also sourced from Pen World Table. Similarly, data on other control variables such as the human capital index is collected from Pen World Table and trade openness as the ratio of export and import to GDP is obtained from WDI.

The variables were converted into their log form before they were used in the regressions analysis. The process of utilizing the variables in log form not only reduces errors but also enables us to obtain elasticity estimates of the variables. The summary statistics of variables and correlation matrix are reported in Table 3. As shown, k, the capital stock per capita, $M O B$, and the interaction of ICT and $B M$ are positively associated with per capita GDP and noticeably have larger connections ranging from 0.91 to 0.95 . $B M$ and REM are positively associated with output at 0.06 and 0.64 respectively. Human capital and trade openness are also positively correlated with real GDP per capita.

Table 3.

Summary Statistics of the Variables

The table provides the summary statistics and correlation matrix of the variables. $y$ is real GDP per capita; $k$ is capital stock per capita; REM is remittances as a percent of GDP, BM is broad money as a percent of GDP; $M O B$ is the mobile subscription per 100 inhabitants, $B M^{*} I C T$ is the interaction term broad money and mobile subscription, $H C$ is human capital and $O P$ is the trade openness.

\begin{tabular}{|c|c|c|c|c|c|c|c|c|}
\hline \multicolumn{9}{|c|}{ Panel A: Descriptive summary of the variables } \\
\hline & $y$ & $k$ & $R E M$ & $B M$ & $M O B$ & $B M * M O B$ & HC & OP \\
\hline Mean & 2455.92 & 19418.52 & 0.66 & 32.87 & 37.00 & 0.04 & 2.14 & 0.41 \\
\hline Median & 2295.42 & 7511.76 & 0.69 & 27.78 & 2.39 & 0.46 & 2.20 & 0.41 \\
\hline Maximum & 4130.66 & 68126.00 & 1.90 & 60.82 & 173.84 & 3.38 & 2.42 & 0.53 \\
\hline Minimum & 1382.12 & 4187.04 & 0.06 & 17.03 & 0.00 & -3.74 & 1.68 & 0.31 \\
\hline Std. Dev. & 786.58 & 21092.03 & 0.49 & 13.15 & 54.09 & 2.63 & 0.23 & 0.06 \\
\hline Skewness & 0.56 & 1.20 & 0.57 & 0.74 & 1.18 & -0.19 & -0.51 & 0.15 \\
\hline Kurtosis & 2.34 & 2.85 & 2.62 & 2.11 & 2.91 & 1.45 & 1.93 & 1.96 \\
\hline Jarque-Bera & 2.41 & 8.16 & 2.07 & 4.23 & 7.96 & 3.61 & 3.10 & 1.67 \\
\hline Probability & 0.30 & 0.02 & 0.36 & 0.12 & 0.02 & 0.16 & 0.21 & 0.43 \\
\hline Observations & 34 & 34 & 34 & 34 & 34 & 34 & 34 & 34 \\
\hline \multicolumn{9}{|c|}{ Panel B: Correlation matrix } \\
\hline & $y$ & $k$ & REM & $B M$ & $M O B$ & $B M^{*} M O B$ & $H C$ & $O P$ \\
\hline$y$ & 1.00 & & & & & & & \\
\hline$k$ & 0.94 & 1.00 & & & & & & \\
\hline REM & 0.64 & 0.47 & 1.00 & & & & & \\
\hline$B M$ & 0.06 & -0.15 & -0.32 & 1.00 & & & & \\
\hline$M O B$ & 0.93 & 1.00 & 0.48 & 0.16 & 1.00 & & & \\
\hline$B M^{*} M O B$ & 0.91 & 0.78 & 0.83 & 0.31 & 0.78 & 1.00 & & \\
\hline $\mathrm{HC}$ & 0.86 & 0.68 & 0.83 & -0.20 & 0.68 & 0.97 & 1.00 & \\
\hline$O P$ & 0.63 & 0.48 & 0.70 & 0.09 & 0.48 & 0.71 & 0.74 & 1.00 \\
\hline
\end{tabular}




\section{B. Results and Discussion}

First, we examine the stationary properties of the variables using ADF and Phillips Perron (PP) unit root tests. The results suggest that the null hypothesis of nonstationary cannot be rejected in levels. However, in the first difference form, the null hypothesis of non-stationary is rejected, indicating variables are I(1). As indicated above, ADF and PP do not account for structural breaks. To address this we use Narayan and Popp's (2010) two-time break test in the series. The results are reported in Table 4 . As observed the unit root hypothesis is rejected for all variables in I(1). It further shows that the real GDP per capita series have two structural breakpoints.

\section{Table 4.}

\section{Unit Root Test Results}

The table provides unit root test results. The values reported are the probability values of rejecting the true null hypothesis. The null hypothesis is that a series has a unit root. asterisks * and ** denote significance at $1 \%$ and $5 \%$ levels, respectively. Critical values are -5.949 at $1 \%,-5.181$ at $5 \%$ and -4.789 at $10 \%$. STB1 and STB2 denote first and second break dates, respectively. The test includes the time trend and intercept. $k$ is lag order and $T$ is sample observation.

\begin{tabular}{lccccc}
\hline Variables & Test-statistic & STB1 & STB2 & $k$ & T \\
\hline$l y$ & $-13.541^{*}$ & 1995 & 1999 & 1 & 34 \\
$l k$ & $-9.086^{*}$ & 1996 & 2008 & 4 & 34 \\
$l M O B$ & $-7.763^{*}$ & 1992 & 1997 & 1 & 34 \\
$l B M$ & -9.244 & 1997 & 2003 & 2 & 34 \\
$l R E M$ & $-7.546^{*}$ & 1996 & 2002 & 4 & 34 \\
$l B M^{*} M O B$ & $-6.218^{* *}$ & 1995 & 2001 & 2 & 34 \\
$H C$ & $-7.378^{* *}$ & 1990 & 2007 & 3 & 34 \\
$O P$ & $-10.061^{*}$ & 1997 & 2003 & 3 & 34 \\
\hline
\end{tabular}

After addressing the unit root properties of the variables, we proceed to examine the long-run relationship between remittances, ICT, FSD, and economic growth. The bounds test results are reported in Table 5. When ly is the dependent variable, the estimated F-statistics is 5.24 and this is greater than the critical value at $5 \%$ level provided by Narayan (2005). As a result, we were able to reject the null hypothesis in favor of the alternative hypothesis. We also ran regression equations with other variables as a dependent variable, where the estimated F-statistics were less than critical values, revealing that the null hypothesis of no cointegration cannot be rejected. Thus, it is confirmed that there is only one cointegration equation and the linkage is in only one direction, that is, when $l y$ is the dependent variable. 
Table 5.

\section{Bounds Test Results}

The table provides the bounds test results from the ARDL model based on Equation (6). The F-statistics rejects the null hypothesis of no cointegration based on per capita real GDP. The test critical values are from Narayan (2005).

\begin{tabular}{llcc}
\hline F-statistics & \multicolumn{2}{c}{5.24} \\
\hline & Narayan (2005) & \\
\hline Level of Significance & I(0) & I(1) \\
\hline $1 \%$ & 4.483 & 6.320 \\
$5 \%$ & 3.120 & 4.560 \\
$10 \%$ & 2.560 & 3.828 \\
\hline
\end{tabular}

Having established the existence of long-run cointegration between output $(l y)$, the dependent variable and independent explanatory variables of capital stock $(l k)$, remittances (lREM), financial sector development (lBM), ICT (lMOB) and the interaction term $\left(l B M^{*} M O B\right)$, we now proceed to estimate the long-run coefficients of the independent variables, which are also the elasticity estimates, and the dynamic short-run Error Correction Model (ECM).

Table 6 presents the estimated long-run and short-run coefficients based on the ARDL technique, as suggested by Pesaran et al (2001). We estimate the ARDL model based on the Schwarz Bayesian Criterion (SBC) to select the optimum lag order. In the long run, the share of the capital stock $(l k)$ is around 0.46 . Being a log-linear model and hence the coefficient being elasticity estimate, a $1 \%$ increase in capital stock per capita, ceteris paribus, leads to a $0.46 \%$ increase in real output per capita. This finding is supplemented by our initial result in Table 3 where the capital stock has a significant positive correlation with output. Indonesia as an emerging economy has also experienced an increase in capital stock over time. This is consistent with the findings of Rath (2019).

The effect of remittances (IREM) on real GDP per capita is positive. With a $p$-value lower than $5 \%$, the estimate is only statistically significant in the long run. The result indicates that a $1 \%$ increase in remittances causes about a $0.02 \%$ increase in real GDP per capita on average in the long run- a relatively small coefficient but reflects the importance of this capital transfer in real GDP per capita. In the short run, the effect is positive however, it lacks significance. This perhaps due to the often-held view that in the short run REM inflows are spent on mostly consumption and not saved and even if it is saved it is not deposited in banks and is likely to be used for uneconomical expenses (Mashayeki, 2014).

The estimated effect of the financial sector development indicator (lBM) is positive and significant in the long run. The estimated elasticity suggests that a $1 \%$ increase in broad money leads to a $0.52 \%$ increase in real GDP per capita. Further, the ICT indicator $(I M O B)$ is found to be positively associated with real GDP per capita, both in the long run and short run. The elasticity coefficient of mobile phones is $0.39 \%$. The spread of ICT in terms of mobile phone usage has a spillover effect in other sectors of the economy including financial markets. The use of mobile phones has enhanced access to financial services and payment systems. In addition to this, the interaction term $\left(I B M^{*} M O B\right)$ emerged with a positive sign and is statistically significant, indicating that ICT and financial sector act in a complementary fashion. 
Moreover, from the long-run estimate, we derive the threshold level of mobile subscriptions which is the indicator for the ICT variable. As the model is in logs, we use the differential of $l y$ with respect to $l B M$ and interactive term of $l B M$ and $I M O B$, and equate its first-order derivative to zero to determine the threshold levels of ICT needed for FSD to contribute to economic growth. We calculate the threshold level for $M O B$ as:

$$
\Delta l y / \Delta l B M=0.527+0.121 l M O B
$$

The threshold level is determined as $0.527 / 0.121=4.355$. The exponential value of the natural logarithm will give us the actual percentage that would be the prerequired level of ICT. Thus, the threshold level of mobile users per 100 inhabitants is about $78 \%$ and that is when the complementary relationship would continue.

The error correction term $\left(E C M_{t-1}\right)$ which has a negative sign is also significant at a $1 \%$ level. This confirms the long-run cointegration relationship between remittances, ICT, FSD, and economic growth. The estimated coefficient of -0.44 indicates that series is not explosive and that any movement away from long-run real GDP per capita in the current period is corrected by around $44 \%$ in the next period. The diagnostic test in Panel-B of Table 6 indicates that the estimation of the results is reliable.

Table 6.

\section{Estimated Long-run and Short-run Results Based on ARDL $(1,0,0,1,0)$ Model}

The table provides long run and short-run elasticity estimates. The asterisks *, **and ${ }^{* * *}$ denote significance at the $1 \%$, $5 \%$ and $10 \%$ level, respectively. In Panel-B, values in brackets are probabilities.

\begin{tabular}{|c|c|c|c|c|c|}
\hline \multicolumn{6}{|c|}{ Panel-A: Estimated coefficient } \\
\hline \multicolumn{3}{|c|}{ Long-run estimates } & \multicolumn{3}{|c|}{ Short-run estimates } \\
\hline Variables & Coefficient & $P$-values & Variables & coefficient & $P$-values \\
\hline$l k$ & 0.468 & $0.062^{* * *}$ & $\Delta l k$ & 0.014 & 0.021 \\
\hline IREM & 0.017 & $0.029^{* *}$ & $\triangle l R E M$ & 0.022 & 0.126 \\
\hline$l B M$ & 0.527 & $0.021^{* *}$ & $\triangle l B M$ & 0.048 & 0.561 \\
\hline$I M O B$ & 0.394 & $0.003^{*}$ & $\triangle l M O B$ & 0.177 & $0.000^{*}$ \\
\hline$l B M^{*} M O B$ & 0.121 & $0.001^{*}$ & $\triangle l B M^{*} M O B$ & 0.019 & $0.030^{*}$ \\
\hline Constant & -9.119 & $0.000^{*}$ & Constant & 4.10 & $0.000^{*}$ \\
\hline \multirow[t]{4}{*}{ Trend } & 0.064 & $0.000^{*}$ & Trend & 0.029 & $0.000^{*}$ \\
\hline & & & $E C M_{t-1}$ & -0.449 & $0.000^{*}$ \\
\hline & & & $R^{2}$ & 0.834 & \\
\hline & & & DW-stats & 2.27 & \\
\hline \multicolumn{6}{|c|}{ Panel-B: Diagnostic tests } \\
\hline Null Hyps & & LM version & $F$ version & & \\
\hline No serial co & $\left.\mathrm{X}^{2}(1)\right]$ & $0.725(0.394)$ & $0.479(0.497)$ & & \\
\hline Correct fun & $\mathrm{m}\left[\mathrm{X}^{2}(1)\right]$ & $0.442(0.506)$ & $0.289(0.597)$ & & \\
\hline Normality [ & & $1.214(0.545)$ & NA & & \\
\hline Homosceda & (1)] & $3.874(0.409)$ & $4.142(0.051)$ & & \\
\hline
\end{tabular}


Further, to check for the robustness of our findings, we use alternative specification by including structural breaks and other control variables such as human capital and trade openness as the regressor along with ICT, FSD, and remittances $^{6}$. We follow the same steps as in the initial specification. The bounds test result $(F$-stat $=6.38)$ shows evidence of a long-run relationship between independent variables and economic growth at a 5\% significance level. The longrun and short-run elasticity estimation is provided in Table 7. The effect of ICT, $F S D$, and remittances appear similar to the findings presented earlier in Table 6. Similarly, the interaction term of ICT and FSD is positive and statistically significant in the long run, which is consistent with the result in Table 6. In addition to this, the effect of human capital and trade openness emerged with a positive sign, indicating a beneficial effect on economic growth. The structural break (SB) point introduced in the model is negative and significant at $5 \%$ level. The estimated coefficient $(S B=-0.069)$ indicates the output decline by $0.069 \%$ in the break periods.

Table 7.

\section{Estimated Long-run and Short-run Results Based on ARDL (1,0,0,1,0) Model with Structural Breaks and Control Variables}

The table provides lon- run and short-run elasticity estimates. The asterisks ${ }^{*}, *$ and ${ }^{* * *}$ denote significance at the $1 \%$, $5 \%$ and $10 \%$ level, respectively. In Panel-B, values in brackets are probabilities. HC is human capital, OP is the trade openness, and $S B$ is the structural break.

\begin{tabular}{|c|c|c|c|c|c|}
\hline \multicolumn{6}{|c|}{ Panel-A: Estimated coefficient } \\
\hline \multicolumn{3}{|c|}{ Long-run estimates } & \multicolumn{3}{|c|}{ Short-run estimates } \\
\hline Variables & Coefficient & $P$-values & Variables & coefficient & $P$-values \\
\hline$l k$ & 0.264 & $0.000^{*}$ & $\Delta l k$ & 0.159 & $0.005^{*}$ \\
\hline IREM & 0.054 & $0.047^{* *}$ & $\triangle I R E M$ & 0.035 & $0.081^{* * *}$ \\
\hline$l B M$ & 0.170 & $0.000^{*}$ & $\triangle \mathrm{lBM}$ & 0.115 & $0.068^{* * *}$ \\
\hline$l M O B$ & 0.159 & $0.005^{*}$ & $\triangle l M O B$ & 0.055 & $0.001^{*}$ \\
\hline$l B M^{*} M O B$ & 0.072 & $0.004^{*}$ & $\triangle l B M^{*} M O B$ & 0.138 & $0.000^{*}$ \\
\hline $\mathrm{HC}$ & 1.159 & $0.059^{* * *}$ & HC & 0.029 & $0.000^{*}$ \\
\hline TO & 0.175 & $0.056^{* * *}$ & TO & 0.035 & $0.083^{* * *}$ \\
\hline$S B$ & -0.069 & $0.025^{* *}$ & $S B$ & -0.015 & 0.327 \\
\hline Constant & 2.211 & $0.000^{*}$ & Constant & 1.879 & $0.000^{*}$ \\
\hline \multirow[t]{4}{*}{ Trend } & 0.015 & $0.000^{*}$ & Trend & 0.011 & $0.002^{*}$ \\
\hline & & & $E C M_{t-1}$ & -0.663 & $0.000^{*}$ \\
\hline & & & $R^{2}$ & 0.923 & \\
\hline & & & DW-stats & 2.47 & \\
\hline \multicolumn{6}{|c|}{ Panel-B: Diagnostic tests } \\
\hline \multicolumn{2}{|c|}{ Null Hypothesis } & LM version & F version & & \\
\hline \multicolumn{2}{|c|}{ No serial correlation $\left[\mathrm{X}^{2}(1)\right]$} & $2.236(0.135)$ & $1.526(0.230)$ & & \\
\hline \multicolumn{2}{|c|}{ Correct functional form $\left[\mathrm{X}^{2}(1)\right]$} & $0.745(0.388)$ & $0.485(0.495)$ & & \\
\hline \multicolumn{2}{|c|}{ Normality $\left[X^{2}(2)\right]$} & $2.443(0.295)$ & NA & & \\
\hline \multicolumn{2}{|c|}{ Homoscedasticity [ $\left.X^{2}(1)\right]$} & $0.681(0.689)$ & $0.653(0.425)$ & & \\
\hline
\end{tabular}

${ }_{6}$ We use this alternative specification based on reviewer suggestion. 
As expected, the estimated coefficient of $E C M_{t-1}$ is negative and statistically significant at $1 \%$ level. The coefficient $(-0.663)$ reinforces the initial finding of the long-run cointegration relationship between growth in output and remittances, along with other conditioning variables. Further, the ECM implies that the speed of adjustment to equilibrium aftershock is relatively rapid, with $66 \%$ convergence in the first period. The effect of ICT, FSD, human capital, and remittances positively influence growth in the short run, but the impact of remittances, FSD, and trade openness are relatively weak. The diagnostic test shows that the results of the cointegration and error correction model are reliable.

\section{CONCLUSION}

This paper examines the role of ICT as a contingent factor in FSD, remittances, and economic growth nexus in Indonesia. Even though several studies investigate the effect of remittance inflow on economic growth or consumption, our attention to ICT and FSD in remittance-growth nexus in Indonesia is another dimension to the extant literature. Besides examining the individual impact of REM, ICT, and FSD, we look at the interaction of ICT and FSD on economic growth. We also calculate the threshold level of ICT that is required for FSD to impact economic growth. We use the neoclassical growth model and ARDL procedure to examine the long run and short effect of REM on economic growth for the period 1984 to 2017. The main findings are as follows. First, remittances inflow show an increasing trend in recent years relative to the 1990s. Second, the initial analysis shows a positive correlation and long-run cointegration between remittances, ICT, FSD, and economic growth. Third, the elasticity coefficient of economic growth with respect to remittances is statistically significant and positive in the long run. This indicates that REM inflow is beneficial for the economic growth process of Indonesia, although the size of this coefficient is relatively small. Other variables such as capital stock, financial development, and ICT exert a positive impact on real GDP per capita in long run. Fourth, the interaction term of ICT and FSD is positive and statistically significant in the long run. This reveals that ICT has indeed emerged a significant factor in the remittances and growth nexus by playing a complementary role in financial sector development. Further, we used an alternative specification based on structural breaks and the different control variables as the regressor. The results are consistent and robust to a different specification. With respect to policy implication, the study shows ICT and FSD are essential for remittances inflow and economic growth. The central and local governments should promote ICT development and financial inclusion among the people including remittances recipients. 


\section{REFERENCES}

Adams, Jr., R. \& Cuecuecha, A. (2010). The Economic Impact of International Remittances on Poverty and Household Consumption and Investment in Indonesia (Policy Research Working Paper 5433). Washington, D.C.: World Bank.

Adams, R., \& Page, J. (2005). Don International Migration and Remittances Reduce Poverty in Developing Countries? World Development, 33, 1645-1669.

Adams R.H. \& Cuecuecha A. (2013). The Impact of Remittances on Investment and Poverty in Ghana. World Development, 50, 24-40.

Aggarwal, R., Demirgüç-Kunt, A., \& Pería, M. (2011), Do Remittances Promote Financial Development? Journal of Development Economics, 96, 255-264.

Aghaei, M. \& Rezagholizadeh, M. (2017). The Impact of Information and Communication Technology (ICT) on Economic Growth in the OIC Countries. Economic and Environmental Studies, 17, 255-276.

Ahmed, E \& Ridzuan, R. (2013). The Impact of ICT on East Asian Economic Growth: Panel Estimation Approach. Journal of the Knowledge Economy, 4, 540555

Amuedo-Dorantes C. \& Pozo S. (2010). Accounting for Remittance and Migration Effects on Children's Schooling. World Development, 38, 1747-1759.

Aziz, I. (2018). Development and shortcomings of Indonesia's financial sector, in Volz, U., Morgan, P.J. E Yoshino, N. (ed). Routledge Handbook of Banking and Finance in Asia, retrieved from https://www.routledgehandbooks.com/ doi/10.4324/9781315543222-5

Bachtiar, P. B. (2011). Migration Outflow and Remittance Patterns in Indonesia: National as well as Subnational Perspective. Philippine Journal of Development No. 70 .

Bettin, G., \& Zazzaro, A. (2009). Remittances and Financial Development: Substitutes or Complements in Economic Growth? (Mo.Fi.R. Working Papers 28). Money and Finance Research Group (Mo.Fi.R.), University Politecnica Marche, Department of Economics, Ancona.

Bosworth, Barry P. \& Collins, M. (2003). The Empirics of Growth: An Update, Brookings Papers on Economic Activity, 2, 113-206.

Calderon, C., Fajnzylber, P. \& Lopez, J. H. (2008). Remittances and growth: the role of complementary policies. In Fajnzylber, P. and Lopez, J. H. (eds), Remittances and Development: Lessons from Latin America. World Bank.

Chakraborty, C. \& Nandi, B. (2003). Privatisation, telecommunications and growth in selected Asian countries: an economic analysis. Communication Strategies, 52, 31-47.

Chami, R., Barajas, A, Cosimano, T., Fullenkamp, C., Gapen, M., \& Montiel, P. (2008). Macroeconomic Impacts of Remittances (IMF occasional paper 259). International Monetary Fund.

Chu, N., Oxley, L. \& Carlaw, K. (2005). ICT and causality in New Zealand economy. Proceedings of the 2005 International conference on simulation and Modelling.

Cronin, F. J., parker, E. B., Colleran, E. K. \& Gold, M.A. (1991). Telecommunications Infrastructure and Economic Growth: An Analysis of Causality. Telecommunication Policy, 15, 529-535.

Dutta, A. (2001). Telecommunications and Economic Activity: An Analysis of Granger Causality. Journal of Management and Information System, 17, 71-95. 
Ebeke, C. (2014). Private saving accelerations. (IMF Working Paper 14/223). International Monetary Fund.

Edwards, A.C. \& Ureta, M. (2003). International Migration, Remittances and Schooling: Evidence from Salvadore. Journal of Development Economics, 51, 387411.

Freund, B., König, H., \& Roth, N. (1997). Impact of Information Technologies on Manufacturing. International Journal of Technology Management, 1, 215-28.

Giuliano, P. \& Ruiz-Arranz, M. (2009). Remittances, Financial Development and Growth, Journal of Development Economics, 90, 144-52.

Hartarto \& M. Azizurrohman (2018). Testing the Gravity model of Remittance Inflows: the case of Indonesia. Paper presented at the 9th International Conference on Socio-economic and Environmental Issues in Development, Hanoi, Vietnam, May 2018.

Hildebrandt, N. \& McKenzie, D.J. (2005). The Effects of Migration on Child Health in Mexico (Policy Research Working Paper Series 3573), World Bank.

ILO. (2015). Indonesia: Decent work for Indonesian Migrant Workers. International Labour Organization. Retrieved from http://www.refworld.org/ pdfid/557fe1bf4.pdf

Ishida, H. (2015). The Effect of ICT Development on Economic Growth and Energy Consumption in Japan. Telematics and Informatics, 32, 79-88.

Jayaraman, T. K., \& Cen, H. (2016). Role of Financial Sector in The RemittancesGrowth Nexus in Fiji. Remittances Review, 1, 17-36.

Jordan J., \& Katz, J. (1999). Banking in the Age of Information Technology. Regional review, 9, 39-50.

Kumar, R. R., Kumar, R. D. \& Patel, A. (2015). Accounting for Telecommunications Contribution to Economic Growth: A Study of Small Pacific Island State. Telecommunications Policy, 39, 284-295.

Leon-Ledesma, M. \& Piracha, M. (2001). International Migration and the Role of Remittances in Eastern Europe, Studies in Economics, Department of Economics, University of Kent.

Lichtenberg, F. (1995). The output contributions of computer equipment and personnel: A firm-level analysis. Economics Innovations and New Technology, 3, 210-217.

Lichtenberg, F.R. (1995). The Output Contributions of Computer Equipment and Personal: A Firmlevel Analysis. Economics of Innovation and New Technology, 3, 201-217.

Majeed, M.T \& T. Ayub (2018). Information and Communication Technology (ICT) and Economic Growth Nexus: A Comparative Global Analysis. Pakistan Journal of Commerce and Social Sciences, 12, 443-476.

Mashayekhi, M. (2014). Remittances and Financial Inclusion. Paper presented at the $13^{\text {th }}$ Coordination Meeting on International Migration, New York 12-13 February 2015, UNCTAD.

Mohan, R., \& Ray, P. (2017). Indian Financial Sector: Structure, Trends and Turns (IMF Working Paper 17/7). International Monetary Fund.

Mongardini, J \& Rayner, B. (2009). Grants, Remittances, and the Equilibrium Real Exchange Rate in Sub-Saharan African Countries (IMF Working Papers 09/75), International Monetary Fund. 
Nahar, F. H., \& Arshad, M. N. M. (2017). Effects of Remittances on Poverty Reduction: The Case of Indonesia. Journal of Indonesian Economy and Business, 32, 163-177. 27.

Nahar, F.H, Adha, A., \& Azizurrohman. (2018). Effects of Remittances on Economic Growth in Indonesia. Paper presented at the 9th, International Conference on Socio-economic and Environmental Issues in Development, Hanoi, Vietnam, May 2018.

Narayan, P.K. (2005). The Saving and Investment Nexus for China: Evidence from Cointegration Tests. Applied Economics, 37, 1979-1990.

Niebel, T. (2018). ICT and Economic Growth-Comparing Developing, Emerging and Developed Countries. World Development, 104, 197-211

Nyamongo, E. M., Misati, R. N., Kipyegon, L., \& Ndirangu, L. (2012). Remittances, financial development and economic growth in Africa. Journal of Economics and Business, 64, 240-260.

Page J. \& Adams, R.H. Jr. (2003). International Migration, Remittances And Poverty In Developing Countries (World Bank Policy Research Working Paper No.3179), World Bank.

Paulson A. \& Townsend, R. (2000). Entrepreneurship and Financial Constraints in Thailand. (Working Paper), Evanston/Chicago, Illinois: Northwestern University.

Parinduri, R.A., \& Thangavelu, S.M. (2011). Impact of Remittances on Human Capital Development of Children in Indonesia Household. Paper presented at the Conference organized by University of Nottingham, Kuala Lumpur 2010 Retrieved on My 13, 2009 from https://www.nottingham.ac.uk/gep/ documents/conferences/2011/malyasia-conf-january/shandre-thangavelu.pdf

Pesaran, M. H., Shin, Y., \& Smith, R. J. (2001). Bounds Testing Approaches to The Analysis of Level Relationships. Journal of Applied Economics, 16, 289-326.

Pradhan, R.P., Arvin. M., Nair, M., Bennett, S., \& Bahmani, S. (2017). ICT-FinanceGrowth Nexus: Empirical Evidence from Next-11 Countries. Cuadermo de economia, 40, 115-124.

Radeck, L., Wenninger J., \& Orlow D. K. (1997). Industry Structure: Electronic Delivery Potential Effects on Retail Banking. Journal of Retail Banking Services, XIX.

Rahman, M.A. (2010). Gender Dimensions of Remittances: A study of Indonesian Domestic Workers in East and Southeast Asia. UNIFEM.

Ramirez, M.D. Sharma, H. (2008). Remittances and Growth in Latin America: A Panel Unit Root and Panel Cointegration Analysis (Working Paper No. 51.). Department of Economics Yale University,

Rao, B.B. (2010). Estimates of the steady state growth rates for selected Asian countries with an extended Solow model. Economic Modelling, 27, 46-53.

Rao, B. \& Rao, M. (2009). Openness and growth in Fiji: some time series evidence. Applied Economics, 41, 1653-1662.

Rao, B. \& Rao, M. (2005). Determinants of Growth Rate: Some Methodological Issues, (School of Economics Working Paper Series,No.25), University of the South Pacific, Fiji Islands

Ratha, D., \& Mohapatra, S. (2007). Increasing the Macroeconomic Impact of Remittances on Development (1-11). Retrieved from http://dilipratha.com/ index_files/G8Berlin.pdf 
Rath, B. N., \& Hermawan, D. (2019). Do Information and Communication Technologies Foster Economic Growth in Indonesia? Bulletin of Monetary Economics and Banking, 22, 103-122.

Rath, B. N. (2016). Does the Digital Divide Across Countries Lead To Convergence? New International Evidence. Economic Modelling, 58, 75-82.

Sekretariat Wakil Presiden Republik Indonesia (2012), National Strategy for Financial Inclusion Fostering Economic Growth and Accelerating Poverty. Retrieved from http://siteresources.worldbank.org/EXTFINANCIALSECTOR/ Resources / 282884 - $1339624653091 / 8703882$ - 1339624678024 / 8703850-1368556147234/Financial-Inclusion-Strategy-Indonesia-2012.pdf, May 20, 2018.

Solow, R. (1956). A Contribution to the Theory of Economic Growth. The Quarterly Journal of Economics, 70, 65-94.

Susilowati, E. \& Leonnard, O. (2019) Factors Influencing Financial Inclusion: Evidence from Indonesian Micro Data. Etikonomi, 18, 121-132.

United Nations. (2015) Millennium Development Goals and post-2015 Development Agenda. http://www.un.org/en/ecosoc/about/mdg.shtml/ post2015developmentframework.shtml, Accessed on August 25, 2016.

United Nations (UN). (2017 a). International Migrant Stock: 1990-2017. UN Department of Economics and Social Affairs, United Nations. Retrieved from https://www.un.org/en/development/desa/population/migration/data/ estimates2/estimates17.asp

Wilson D. (1993). Assessing the impact of information technology on organizational performance. In R. Banker, R. Kanffan and M. Mahmood (ed). Hansbury: Strategic information technology management idea group.

World Bank Group (2017a). Migration and Remittances: recent Developments and Outlook ( Development Brief 29). World Bank. http://www.worldbank.org/en/ topic/migrationremittancesdiasporaissues, accessed on June 202017.

World Bank (2017b). Financial Sector Assessment: Republic of Indonesia. Wold Bank: Retrieved from documents.worldbank.org/curated/en/.../Indonesia-FSAPUpdate-FSA-07072017.pdf

World Bank Group (2018). Migration and Remittances: Recent Developments and Outlook (Migration and Development Brief 30). World Bank.

World Bank (2019). World Development Indicators, Washington, D.C.: World Bank, Retrieved on May 272019 from https://databank.worldbank.org/data/reports. aspx?source=world-development-indicators\#

Yang, D. (2008). International Migration, Remittances and Household Investment: Evidence from Philippines. Economic Journal, 118, 591-630. 
This page is intentionally left blank 